\title{
Inhibitory effect of Allium sativum and Zingiber officinale extracts on clinically important drug resistant pathogenic bacteria
}

\author{
Iram Gull, Mariam Saeed, Halima Shaukat, Shahbaz M Aslam, Zahoor Qadir Samra and Amin M Athar
}

\begin{abstract}
Background: Herbs and spices are very important and useful as therapeutic agent against many pathological infections. Increasing multidrug resistance of pathogens forces to find alternative compounds for treatment of infectious diseases.

Methods: In the present study the antimicrobial potency of garlic and ginger has been investigated against eight local clinical bacterial isolates. Three types of extracts of each garlic and ginger including aqueous extract, methanol extract and ethanol extract had been assayed separately against drug resistant Escherichia coli, Pseudomonas aeruginosa, Bacillus subtilis, Staphylococcus aureus, Klebsiella pneumoniae, Shigella sonnei, Staphylococcus epidermidis and Salmonella typhi. The antibacterial activity was determined by disc diffusion method.

Results: All tested bacterial strains were most susceptible to the garlic aqueous extract and showed poor susceptibility to the ginger aqueous extract. The (minimum inhibitory concentration) MIC of different bacterial species varied from $0.05 \mathrm{mg} / \mathrm{ml}$ to $1.0 \mathrm{mg} / \mathrm{ml}$.

Conclusion: In the light of several socioeconomic factors of Pakistan mainly poverty and poor hygienic condition, present study encourages the use of spices as alternative or supplementary medicine to reduce the burden of high cost, side effects and progressively increasing drug resistance of pathogens.
\end{abstract}

Keywords: Garlic, Ginger, Antibacterial activity, Extracts

\section{Introduction}

Microbial pathogenecity and other infectious diseases have been controlled by use of commercially available antimicrobial drugs since last many years. Tremendous use of antibiotics has developed multiple drug resistance (MDR) in many bacterial pathogens. The increasing drug resistance is the main hindrance in successful treatment of infectious diseases and to the control of microbial pathogenecity [1]. Similarly, preservatives like sulfites, nitrates, nitrites and antibiotics, are harmful for human health and have many side effects including headache, nausea, weakness, mental retardation, seizures, cancer and anorexia [2]. Development of drug resistance in pathogens and increasing interest of consumers for safe food forces to explore new antimicrobial agents [3].

\footnotetext{
*Correspondence: iramgull86@yahoo.com

Institute of Biochemistry and Biotechnology, University of the Punjab, Quaid-iAzam Campus, Lahore, Pakistan
}

Natural products are a major source of new natural drugs and their use as an alternative medicine for treatment of various diseases has been increased in the last few decades $[4,5]$. In comparison to the formulated drugs the herbs and spices have fewer side effects. They are also inexpensive, show better patient tolerance and are readily available for low socioeconomic populatation [6]. In recent years, in view of their beneficial effects, use of spices or herbs is gradually increasing not only in developing countries but also in developed countries [7].

The antimicrobial activity of spices is due to specific phytochemicals or essential oils [8]. The main factors that determine the antimicrobial activity are the type and composition of the spice, amount used, type of microorganism, composition of the food, $\mathrm{pH}$ value and temperature of the environment [9]. Several reports had been published that describe the antibacterial and antifungal properties of different herbs and spices. However, 
still there is little information about the exact mechanism of their antimicrobial action [10-16].

In the present study, in vitro antimicrobial activity of some local spices of Pakistan, that are routinely used in food, has been investigated against clinically important bacterial pathogens.

\section{Materials and methods Sample collection}

Garlic (Allium sativum) and ginger (Zingiber officinale) used in the present study were purchased from the local market of Lahore, Pakistan.

\section{Bacterial strains}

Eight different characterized drug resistant bacterial strains including S. typhi, Shigella, P. aeruginosa, E. coli, B. subtillus, S. aureus, S. epidermidis and K. pneumoniae were obtained from Sheikh Zayed hospital and Jinnah hospital, Lahore, Pakistan. The strains were maintained on Nutrient agar slants.

\section{Preparation of extracts}

Three types of extracts such as aqueous, ethanol and methanol extract from each garlic and ginger were prepared separately. The fresh garlic cloves and ginger rhizomes were washed, peeled, sliced and sun dried for seven days. After drying, garlic and ginger slices were ground to fine powder separately using electric blender. $10 \mathrm{~g}$ powder of each garlic and ginger was soaked in $100 \mathrm{ml}$ of distilled water, ethanol and methanol separately. The flasks were incubated at room temperature for 72 hours with shaking at $120 \mathrm{rpm}$. The crude extracts were centrifuged at $3000 \mathrm{rpm}$ for 10 minutes at $25^{\circ} \mathrm{C}$. The methanol and ethanol extracts were evaporated at $50^{\circ} \mathrm{C}$ while the aqueous extracts were evaporated at $80^{\circ} \mathrm{C}$ in rotary evaporator. All dried extract samples were dissolved in distilled water separately to the final concentration of $100 \mathrm{mg} / \mathrm{ml}$ and centrifuged again at 10,000 rpm to remove the undissolved residues. The extract solutions were stored at $4^{\circ} \mathrm{C}$. Garlic aqueous, ethanol and methanol extracts were named as GaAE, GaEE and GaME respectively while ginger aqueous, ethanol and methanol extracts were named as GiAE, Gi EE and GiME respectively. The controls methanol, ethanol and water were treated in similar fashion as described for extract preparation and checked for antimicrobial activity.

\section{Culture preparation}

The bacterial strains were inoculated in $1 \mathrm{ml} \mathrm{LB}$ broth and grown overnight at $37^{\circ} \mathrm{C}$ separately before performing antimicrobial assay. The $50 \mu \mathrm{l}$ of overnight culture of each bacterial strain was transferred separately into $5 \mathrm{ml}$ of LB broth ( $\mathrm{pH} 7.2)$ under sterile conditions and placed in shaking water bath at $37^{\circ} \mathrm{C}$ for 16 hours. The bacterial cells were harvested at $3000 \mathrm{rpm}$ for 15 minutes at $4^{\circ} \mathrm{C}$, washed twice with phosphate buffer saline ( $\mathrm{pH} 7.4)$ and resuspended in LB broth. The inoculum concentration was adjusted to $10^{7} \mathrm{CFU} / \mathrm{ml}$.

\section{Antimicrobial assay using Disc diffusion method}

The antimicrobial assay of spices was performed by disc diffusion method as described by Kirby-Bauer [17]. All the experiments were performed under sterile conditions. The nutrient agar plates were inoculated separately with $10^{7} \mathrm{CFU}$ of each test bacterial strain culture and evenly spread on entire surface of each plate. The sterile discs (5 mm diameter) were dipped aseptically in different extracts for one minute and placed over nutrient agar plates seeded with bacterial culture. The plates were left at ambient temperature for 15 minutes and then incubated at $37^{\circ} \mathrm{C}$ for 16 hours and observed for zone of inhibition. The diameter of inhibition zones was measured in milimeters. Antimicrobial assay was performed in triplicate with each bacterial strain.

Determination of minimum inhibitory concentration (MIC) MIC of different garlic and ginger extracts was determined by the method described by Natta et al [18] after minor modifications. The extracts were diluted ranging from $100 \mathrm{mg} / \mathrm{ml}$ to $0.01 \mathrm{mg} / \mathrm{ml}$ and checked for MIC against bacterial strains. Sterile discs were dipped in different dilutions of aqueous, ethanol and methanol extracts of garlic and ginger and placed over LB agar plates seeded with $10^{7} \mathrm{CFU}$ of each bacterial cultures separately. Plates were placed at $37^{\circ} \mathrm{C}$ for 16 hours. The zone of inhibition in each case was measured as the diameter of the clearing zones and results were recorded. Each experiment was performed in triplicate.

\section{Statistical analysis}

Values are mean of \pm SD (standard deviation) of three replicates.

\section{Results and Discussion}

Use of garlic and ginger as a natural supplement is considered healthy choice for the treatment of cardiovascular diseases [19,20], hypertension [21], diabetes [22]. Alzheimer's disease [23,24], inflammation, thrombosis [25] and even for cancer [26]. Recently ginger was also reported for treatment of nonalcoholic fatty liver diseases, [27]. With the increasing awareness of population toward natural therapies, spices can be considered as obvious alternate medication [28].

In the present study antibacterial effect of garlic and ginger was evaluated by disc diffusion method. The results indicated that different extracts of spices have broad spectrum antibacterial activity with variable degree of sensitivity of tested bacterial species toward these 
extracts. The controls did not show any antimicrobial activity. The data presented in Table 1 shows that garlic aqueous extract exhibited highest antibacterial activity against all tested bacteria except E. coli and Shigella. Garlic methanol extract was least effective against all tested bacteria. The antimicrobial activity shown by garlic extracts in this study agrees with the findings of others [13,14,29-31].

The results given in Table 1 show that ginger methanol and ethanol extracts are more effective against all tested bacterial strains than ginger aqueous extracts. E. coli and Shigella were also more susceptible to the ginger extracts. E. coli showed maximum susceptibility to the ginger ethanol extracts while Shigella showed maximum susceptibility to both ginger methanol and ethanol extract. The results of antimicrobial effect of ginger in the study are in accordance with most of the reports published regarding ginger antimicrobial activity [32-36]. The antibacterial activities of the extracts are expected perhaps due to the compounds like flavonoids and volatile oil which were dissolved in organic solvents. It is reported that sesquiterpenoids are the main component of ginger which attributes its antibacterial activity [35]. The results obtained in our study corroborate with the report of Roy et al [37], which explains that bioactive compounds of ginger rendering antimicrobial activity are volatile in nature and antimicrobial activity of ginger extract decreases upon storage. In addition to water, methanol and ethanol were also used for extract preparation as de Boer et al [38] has reported that bioactive compounds show better solubility in water miscible organic solvents.

The order of antibacterial activity of different garlic and ginger extracts against tested clinical isolates of pathogenic bacteria was as follow: 1) E. coli, GiEE> GiME $>G a A E>G i A E>G a M E>G a E$; 2) P. aeruginosa, $G a A E>G i E E>G i M E>G a E E>G i A E>G a M E$; 3) Bacillus subtilis, GaAE>GiEE $>$ GaEE $>$ GiAE $>$ GaME $>$ GiME; 4) Shigella, GiEE, GiME $>$ GaEE $>$ GaAE $>$ GiAE $>$ GaME; 5) S.aureus, GaAE $>$ GiME $>$ GiEE, GiAE > GaEE $>$ GaME; 6) K. pneumoniae, GaAE $>$ GaEE>
GiME $>$ GiEE, GiAE, GaME; 7) S.epidermidis, GaAE> $G i E E>G i A E>G i M E>G a E E>G a M E ; \quad 8)$ S.typhi, $G a A E>G i M E>G i E E>G i A E>G a E E>G a M E$.

The minimum inhibitory concentration (MIC) was determined by making the dilutions of different extracts of garlic and ginger ranging from $100 \mathrm{mg} / \mathrm{ml}$ to $0.01 \mathrm{mg} / \mathrm{ml}$. The MIC values of different garlic and ginger extracts are summarized in Figures 1 and 2 respectively. The results showed that MIC of different extracts of garlic and ginger against bacterial strains ranged from $0.05 \mathrm{mg} / \mathrm{ml}$ to $1.0 \mathrm{mg} / \mathrm{ml}$. The data in Figure 1 indicated that all tested strains were susceptible to garlic aqueous, methanol and ethanol extract but most effective was garlic aqueous extract. From all MIC values of different garlic extracts, lowest MIC values for E. coli, P. aeruginosa, B. subtilis, S. aureus, K. pneumoniae, S. epidermidis and S. typhi were $0.1 \mathrm{mg} / \mathrm{ml}, 0.09 \mathrm{mg} /$ $\mathrm{ml}, 0.1 \mathrm{mg} / \mathrm{ml}, 0.2 \mathrm{mg} / \mathrm{ml}, 0.2 \mathrm{mg} / \mathrm{ml}, 0.09 \mathrm{mg} / \mathrm{ml}$ and $0.02 \mathrm{mg} / \mathrm{ml}$ respectively with garlic aqueous extract except Shigella which showed lowest MIC value $(0.07 \mathrm{mg} / \mathrm{ml})$ with garlic methanol extract. Ethanol and methanol extract of ginger had lower MIC in comparison to the ginger aqueous extract against tested bacterial strains (Figure 2). In case of different ginger extracts, the lowest MIC value for $E$. coli $(0.08 \mathrm{mg} / \mathrm{ml}), \quad$ P. aeruginosa $(0.4 \mathrm{mg} / \mathrm{ml}), \quad B$. subtilis $(0.3 \mathrm{mg} / \mathrm{ml})$ and $S$. epidermidis $(0.05 \mathrm{mg} / \mathrm{ml})$ was observed with ginger methanol extract while for $S$. aureus $(0.3 \mathrm{mg} /$ $\mathrm{ml})$, K. pneumoniae $(0.05 \mathrm{mg} / \mathrm{ml})$ and S. typhi $(0.08 \mathrm{mg} / \mathrm{ml})$ was observed with ginger ethanol extract. The ginger methanol and ethanol extract showed lowest and same MIC value for Shigella $(0.05 \mathrm{mg} / \mathrm{ml})$.

The decreasing susceptibility of tested pathogenic bacteria was observed in this order: S.epidermidis $>$ S.aureus $>$ B. subtilis $>P$. aeruginosa $>K$. pneumoniae $=$ S.typh $i>$ E. coli=Shigella. It was interesting to note that clinical isolates, both Gram negative and Gram positive bacteria were sensitive to all tested extracts of garlic and ginger but Gram positive bacteria were more sensitive than Gram negative bacteria. This result is in accordance with the findings of Chandarana [39]; Onyeagba [40] and deSouza [41]

Table 1 Antibacterial activity of spices extracts measured as diameter $(\mathrm{mm})$ of zone of inhibition

\begin{tabular}{|c|c|c|c|c|c|c|}
\hline & \multicolumn{3}{|l|}{ Garlic } & \multicolumn{3}{|l|}{ Ginger } \\
\hline & Aqueous Extract & Ethanol Extract & Methano Extract & Aqueous Extract & Ethanol Extract & Methanol Extract \\
\hline E.coli & $14.3 \pm 0.54$ & $11.6 \pm 0.27$ & $12 \pm 0$ & $12.3 \pm 0.27$ & $15 \pm 0.47$ & $14.5 \pm 0.27$ \\
\hline P. aeruginos & $18.3 \pm 0.72$ & $13.3 \pm 0.27$ & $11 \pm 0$ & $13 \pm 0.47$ & $14 \pm 0.94$ & $13.6 \pm 0.54$ \\
\hline B. subtilis & $18.6 \pm 0.27$ & $13.3 \pm 0.54$ & $12 \pm 0$ & $12.3 \pm 0.27$ & $13.6 \pm 0.27$ & $11.3 \pm 0.27$ \\
\hline Shigella & $13 \pm 0.47$ & $13.3 \pm 0.54$ & $11 \pm 0$ & $11.6 \pm 0.27$ & $15 \pm 0.47$ & $15 \pm 0.47$ \\
\hline S. aureus & $19.3 \pm 1.08$ & $12.6 \pm 0.27$ & $11 \pm 0$ & $13 \pm 0.47$ & $13 \pm 0$ & $14.3 \pm 0.27$ \\
\hline K. pneumoniae & $15.6 \pm 0.54$ & $14 \pm 0.47$ & $11 \pm 0$ & $11 \pm 0$ & $11 \pm 0$ & $12 \pm 0.81$ \\
\hline S. epidermidis & $22 \pm 0.47$ & $11.6 \pm 0.27$ & $11 \pm 0$ & $12.6 \pm 0.27$ & $15 \pm 0.47$ & $12 \pm 0$ \\
\hline S.typhi & $15.6 \pm 0.56$ & $11 \pm 0$ & $11 \pm 0$ & $11 \pm 0$ & $11.3 \pm 0.27$ & $11.7 \pm 0.32$ \\
\hline
\end{tabular}




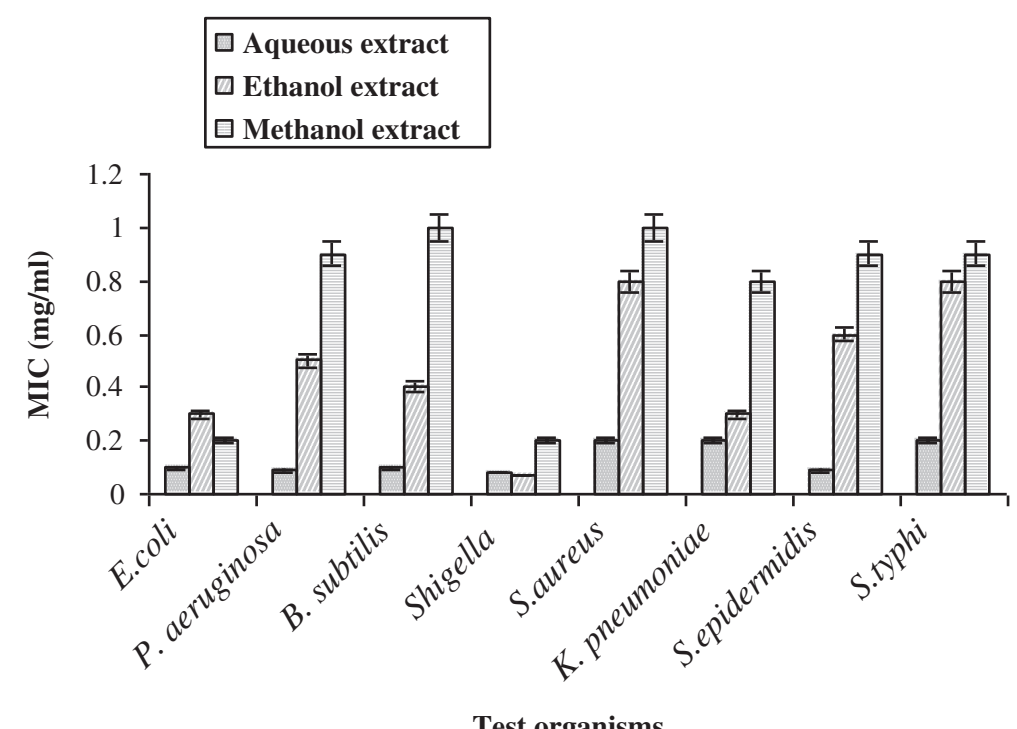

Figure 1 Minimum inhibitory concentration (MIC) of different garlic extracts against tested bacterial isolates.

It is established in the study that spices reduce and inhibit the growth of food pathogens therefore the use of spices would decrease the chances of food poisoning and increase the food shelf life. Several socioeconomic factors are major cause of miserable health condition of poor people of Pakistan which includes; poverty, unhygienic conditions, overcrowding, contamination of food /water by poor sanitary practices, limited awareness of seriousness of foodborne diseases and importance of hygiene. While living in such conditions, use of spices (garlic/ginger) in diet can reduce the risk of food contamination, protect the consumer from different foodborne diseases, improve their health status and combat with the foodborne diseases by using small quantity of spices (garlic/

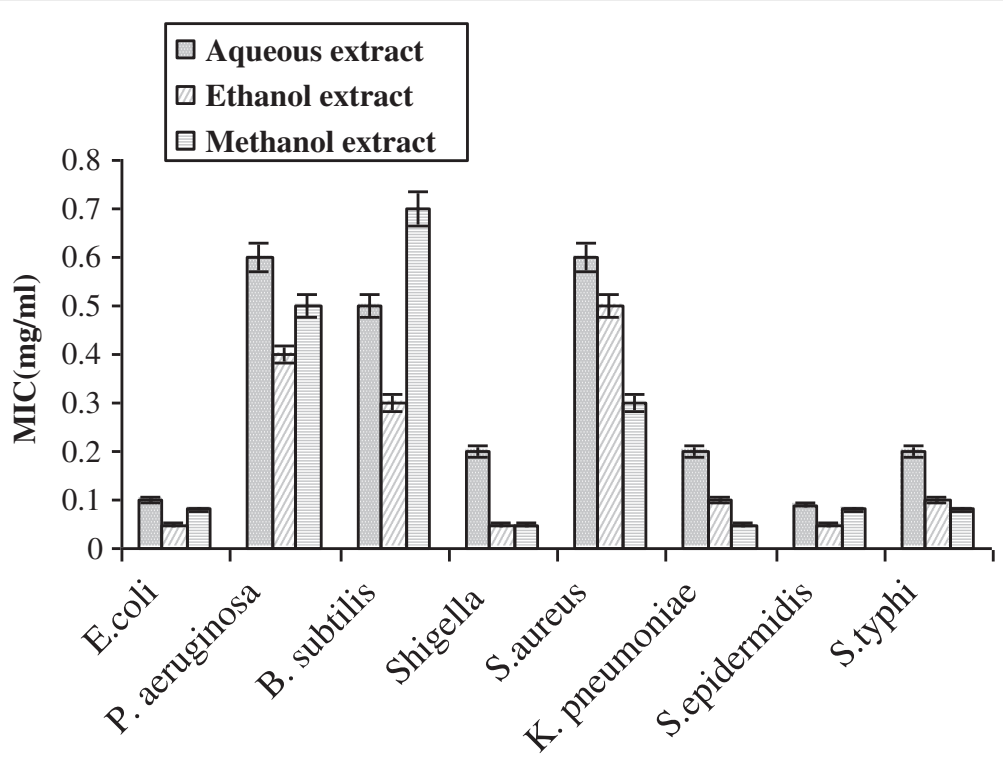

Test organisms 
ginger) in diet. In this study heat effect on antimicrobial activity of garlic and ginger was not checked as it is already reported that antimicrobial activity of garlic is affected by heating at $100^{\circ} \mathrm{C}$ for $30-60$ minutes [42]. Therefore, it is recommended to use garlic and ginger in different raw forms like pickle, garlic/ginger bread, curry powder, sauces, raw juices and without extensive cooking.

In conclusion, the results of present study have provided the justification for therapeutic potential of spices. The practice of using spices as supplementary or alternative medicine in developing countries like Pakistan will not reduce only the clinical burden of drug resistance development but also the side effects and cost of the treatment with allopathic medicine. Further clinical evaluation of spices in in vivo experiments is required to be carried for low cost treatment with few side effects and for prevention of recurrent infection.

\section{Competing interest}

The authors declare that they have no competing interests.

\section{Authors' contribution}

All authors equally participated in designing experiments, acquisition, analysis and interpretation of data. Prof. Amin Athar critical revise the manuscript and approved the final version of manuscript. All authors read and approved the final manuscript

Received: 16 January 2012 Accepted: 21 April 2012

Published: 27 April 2012

\section{References}

1. Fu YJ, Zu YG, Chen LY, Shi XHG, Wang Z, Sun S, Efferth T: Antimicrobial Activity of clove and rosemary essential oils alone and in combination. Phytother Res 2007, 21:989-999.

2. Rangan C, Barceloux DG: Food additives and sensitivities. Dis Mon 2009, 55:292-311.

3. Erdogrul OT: Antibacterial activities of some plant extracts used in folk medicine. Pharm Biol 2002, 40:269-273.

4. Vuorelaa P, Leinonenb M, Saikkuc P, Tammelaa P, Rauhad JP, Wennberge T, Vuorela $\mathrm{H}$ : Natural products in the process of finding new drug candidates. Curr Med Chem 2004, 11:1375-1389.

5. Ansari MA, Ahmed SP, Haider S, Ansari NL: Nigella sativa: A nonconventional herbal option for the management of seasonal allergic rhinitis. Pak J Pharm 2006, 23:31-35.

6. Adeshina GO, Jibo S, Agu VE, Ehinmidu JO: Antibacterial activity of fresh juices of Allium cepa and Zingiber officinale against multidrug resistant bacteria. Int J Pharma Biosci 2011, 2:289-295.

7. Duman-Aydyn B: Investigation of antibacterial effects of some medicinal plants and spices on food pathogens. Kafkas Univ Vet Fak Derg 2008, 14:83-87.

8. Avato $P$, Tursil $E$, Vitali $C$, Miccolis V, Caddido V: Allyl sulfide constituents of garlic volatile oil as antimicrobial agents. Phytomed 2000, 7:239-243.

9. Sagdic O: Sensitivity of four pathogenic bacteria to Turkish thyme and wild marjoram hydrosols. Lebensm Wiss Technol 2003, 36:467-473.

10. Gur S, Turgut-Balik D, Gur N: Antimicrobial activities and some fatty acids of turmeric, ginger root and linseed used in the treatment of infectious dideses. World j Agri Sci 2006, 2:439-442.

11. Pattaratanawadee E, Rachtanapun C, Wanchaitanawong P, Mahakarnchanakul W: Antimicrobial activity of spice extracts against pathogenic and spoilage microorganisms. Kasetsart J Nat Sci 2006, 40:159-165.

12. Yusha'u M, Garba $L$, Shamsuddeen U: In vitro inhibitory activity of garlic and ginger extracts on some respiratory tract isolates of gram-negative organisms. Int J Biomed HIth Sci 2008, 4:57-60.

13. Belguith H, Kthiri F, Chati A, Sofah AA, Hamida JB, Landoulsi A: Study of the effect of aqueous garlic extract (Allium sativum) on some Salmonella serovars isolates. Emir J Food Agric 2010, 22:189-206.
14. Yin MC, Chang HC, Tsao SM: Inhibitory Effects of aqueous garlic extract, garlic oil and four diallyl sulphides against four enteric pathogens. J Food Drug Anal 2002, 10:120-126.

15. Oskay M, Oskay D, Kalyoncu F: Activity of some plant extracts against multidrug resistant human pathogens. Iranian J Pharmacol Res 2009, 8:293-300.

16. Poeloengan M: The effect of red ginger (Zingiber officinale Roscoe) extract on the growth of mastitis causing bacterial isolates. Afr J Microbiol Res 2011, 5:382-389.

17. Kirby-Bauer A: Antimicrobial sensitivity testing by agar diffusion method. J Clin Pathol 1996, 44:493.

18. Natta L, Orapin K, Krittika N, Pantip B: Essential oil from five Zingiberaceae for anti food-borne bacteria. Int Food Res J 2008, 15:337-346.

19. Mahmoodi M, Islami MR, Karam AGR, Khaksari M, Sahebghadam LA, Hajizadeh MR, Mirzaee MR: Study of the effects of raw garlic consumption on the level of lipids and other blood biochemical factors in hyperlipidemic individuals. Pak J Pharm Sci 2006, 19:295-298.

20. Bordia A, Verma SK, Srivastava KC: Effect of ginger (Zingiber officinale Rosc.) and fenugreek (Trigonella foenumgraecum L.) on blood lipids, blood sugar and platelet aggregation in patients with coronary artery disease. Prostaglandins Leukot Essent Fatty Acids 1997, 56:379-384.

21. Benavides GA, Squadrito GL, Mills RW, Patel HD, Isbell TS, Patel RP, Darley-Usmar VM, Doeller JE, Kraus DW: Hydrogen sulfide mediates the vasoactivity of garlic. PNAS 2007, 104:17977-17982.

22. Banerjee SK, Maulik SK: Effect of garlic on cardiovascular disorders: a review. Nutr J 2002, 1:4.

23. Peng Q, BuzZard AR, Lau BH: Neuroprotective effect of garlic compounds in amyloid-beta peptide-induced apoptosis in vitro. Med Sci Monit 2002, 8:328-337.

24. Chauhan NB: Effect of aged garlic extract on APP processing and tau phosphorylation in Alzheimer's transgenic model Tg2576. $J$ Ethnopharmacol 2006, 108:385-394.

25. Fukao H, Yoshida H, Tazawa Yl, Hada T: Antithrombotic Effects of odorless garlic powder both in vitro and in vivo. Biosci Biotechnol Biochem 2007, 71:84-90.

26. Hsing AW, Chokkalingam AP, Gao YT, Madigan MP, Deng J, Gridley G, Fraumeni JF: Jr Allium vegetables and risk of prostate cancer: a population-based study. J Natl Cancer Inst 2002, 94:1648-1651.

27. Sahebkar A: Potential efficacy of ginger as a natural supplement for nonalcoholic fatty liver disease. World J Gastroenterol 2011, 17:271-272.

28. Sofia PK, Prasad R, Vijay VK, Srivastava AK: Evaluation of antibacterial activity of Indian spices against common foodborne pathogens. Int J Food Sci Technol 2007, 42:910-915.

29. Bakht J, Tayyab M, Ali H, Islam A, Shafi M: Effect of different solvent extracted sample of Allium sativum (Linn) on bacteria and fungi. Afr J Biotechnol 2011, 10:5910-5915.

30. Iwalokun BA, Ogunledun A, Ogbolu DO, Bamiro SB, Jimi-Omojola J: In Vitro antimicrobial properties of aqueous garlic extract against multidrug-resistant bacteria and candida species from Nigeria. J Med Food 2004, 7:327-333.

31. O'Gara EA, Hill DJ, Maslin DJ: Activities of garlic oil, garlic powder, and their diallyl constituents against Helicobacter pylori. Appl Environ Microbiol 2000, 66:2269-2273.

32. Sebiomo A, Awofodu AD, Awosanya AO, Awotona FE, Ajayi AJ: Comparative studies of antibacterial effect of some antibiotics and ginger (Zingiber officinale) on two pathogenic bacteria. J Microbiol Antimicro 2011, 3:18-22.

33. Gao D, Zhang Y: Comparative antibacterial activities of crude polysaccharides and flavonoids from Zingiber officinale and their extraction. Asian j Trad Med 2010, 5:235-238.

34. Yu J, Yun CH, Gao ZJ, Zhao XF, Xiao CN, Fang MF, Zheng XH: Study on antimicrobial of ginger extracting components. Nat Prod Res Dev 2009, 21:459-461.

35. Malu SP, Obochi GO, Tawo EN, Nyong BE: Antibacterial activity and medicinal properties of ginger (Zingiber officinale). Global J Pure Appl Sci 2008, 15:365-368.

36. Akoachere JF, Ndip RN, Chenwi EB, Ndip LM, Njock TE, Anong DN: Antibacterial effect of Zingiber officinale and Garcinia kola on respiratory tract pathogens. East Afr Med J 2002, 79:588-592.

37. Roy J, Shakaya DM, Callery PS, Thomas JG: Chemical constituents and antimicrbila activity of a traditional herbal medicine containing garlic and black cumen. Afr J Trad 2006, 3:1-7.

38. de Boer HJ, Kool A, Mizirary WR, Hedberg I, Levenfors JJ: Antifungal and antibacterial activity of some herbal remedies from Tanzania. $J$ Ethanopharmacol 2005, 96:461-469. 
39. Chandarana H, BAluja S, Chanda SV: Comparison of Antibacterial Activities of Selected Species of Zingiberaceae Family and Some Synthetic Compounds. Turk J Biol 2005, 29:83-97.

40. Onyeagba RA, Ugbogu OC, Okeke CU, Iroakasi O: Studies on the antimicrobial effects of garlic (Allium sativum Linn), ginger (Zingiber officinale Roscoe) and lime (Citrus aurantifolia Linn). Afr J Biotechnol 2004, 3:552-554.

41. De-Souza EL, Stamford TLM, Lima EO, Trajano VN, Filho JMB: Antimicrobial Effectiveness of Spices: an Approach for Use in Food Conservation Systems. Brazilian Arch Biol and Technol 2005, 48:549-558.

42. Al-Waili NS, Saloom KY, Akmal M, Al-Waili TN, Al-Waili AN, Al-Waili H, Ali A, Al-Sahlani K: Effects of heating, storage, and ultraviolet exposure on antimicrobial activity ofgarlic juice. J Med Food 2007, 10:208-212.

doi:10.1186/1476-0711-11-8

Cite this article as: Gull et al:: Inhibitory effect of Allium sativum and Zingiber officinale extracts on clinically important drug resistant pathogenic bacteria. Annals of Clinical Microbiology and Antimicrobials 2012 $11: 8$

\section{Submit your next manuscript to BioMed Central and take full advantage of:}

- Convenient online submission

- Thorough peer review

- No space constraints or color figure charges

- Immediate publication on acceptance

- Inclusion in PubMed, CAS, Scopus and Google Scholar

- Research which is freely available for redistribution 